\title{
A Postcolonial Scrutiny of the Media Imperialism in Wajahat Ali's The Domestic Crusaders
}

\author{
Maram Mohammed Samman \\ Department of Languages and Translation \\ College of Arts and Humanities, Taibah University, \\ Madinah, Saudi Arabia \\ Email: Email: mmsamman@taibhu.edu.sa
}

Received: 11/15/2020

Accepted: $1 / 5 / 2021$

Published: $2 / 24 / 2021$

\begin{abstract}
The paper reevaluates Wajahat Ali's play The Domestic Crusaders through the postcolonial views of Edward Said. It explores the role of the Western media in the classification and alienation of Muslims according to racist misconceptions. Despite the differences in their respective approaches, the two texts-Ali's The Domestic Crusaders and Said's Covering Islam-denounce the media's role in the distortion of the portrayals of Islam and Muslims. Accordingly, the study aims at discussing the two texts through a postcolonial viewpoint in relation to the media's role in the spread of Islamophobia. Extracts from both texts will be provided to explicitly or implicitly epitomize the dilemma of the Muslim society after 9/11. The paper explores how the media exploit the fear, ignorance, or vulnerabilities of the global audience. The paper proves that the crusades against Islam deliberately and erroneously describe it as a source of violence and primitiveness that threatens humankind.

Keywords: Covering Islam, Edward Said, 9/11 events, Islamophobia, media imperialism, postcolonial readings, terrorism, The Domestic Crusaders, Wajahat Ali

Cite as: Samman, M. M. (2021). A Postcolonial Scrutiny of the Media Imperialism in Wajahat Ali's The Domestic Crusaders. Arab World English Journal for Translation \& Literary Studies 5 (1) 234 -247. DOI: http://dx.doi.org/10.24093/awejtls/vol5no1.17
\end{abstract}




\section{Introduction}

Much of what is known about Islam and Muslims in Western societies is derived from the mass media. Studies have shown that over three-quarters of people in Western societies rely on the mass media, mainly television, as their primary source of information about Islam and Muslims. (Rane, Ewart, \& Martinkus, 2014, p. 29)

After 9/11/2001, a widespread Islamophobic trend has prevailed in the world. Muslims have to tolerate open enmity and active hatred. It is a publicly acknowledged fact that the events of 9/11 have created a negative and irrevocable image of all Muslims as terrorists. This paper warns against the fact that everyone is being valued according to criteria based on appearances. Depending on the political, social, and cultural complications of 9/11 and the subsequent fiction that addresses this particular context, this article aims, at first, to focus on the role of the modern media in subjugating and neo-colonizing nations, as represented in Wajahat Ali's The Domestic Crusaders. The play essentially depicts twenty-four hours in the life of three generations of a PakistaniAmerican who are celebrating the birthday of their third son, Ghafur. Second, the paper attempts to reread this play in the light of Islamophobia and Islamic tolerance due to the unequal relations between Eastern and Western civilizations. It considers the play as a cry against all Muslims' stereotyping as members of Al-Qaeda or ISIS by the media.

Third, the paper critically evaluates Ali's play with Said's (1997) "third and last in a series of books; Orientalism, The Question of Palestine, and Covering Islam" which are considered the "main cornerstone for postcolonialism and cultural studies" (p. i). Said deliberates on the effects of Western media on the one hand and that of power, hegemony, and knowledge on the other. Fourth, in light of the two texts, the paper discusses the responsibility of the American and Western media in the creation of the current situations of intolerance that these Muslim characters find themselves in. In the play, the media's role is as decisive as the voices of Television and Radio that could silence the family to announce or comment on the news. In Covering Islam, Said (1997) asserts the role of the Western media in the propagation of Islamophobia in the name of realism, liberalism, and freedom. The two texts discuss the idea put forward in Said's words, "Islam is peculiarly traumatic news today in the West" (p. 1).

Besides, the paper discusses possible answers to the questions: Are Muslims and Islam to be considered the enemies of the West? Is it right to profile all Muslims as terrorists? Can we differentiate between Islam and Muslims? In fact, all discussions of terrorism should center on these trajectories. Islam's beliefs are frequently distorted and taken out of context, with practices being taken to represent a rich and complex faith. The injustice of Islamophobia is that it confuses small groups of terrorists with the majority of Muslims. Moreover, the supporters of Islamophobia went from being afraid of Islam to launching wars against it with more of a militant and aggressive crusader-like agenda - something that is the essence of both the play and the book.

Arab World English Journal for Translation \& Literary Studies 
As a Pakistani-American journalist, playwright, and lawyer, Ali is among those Muslim writers who assiduously "strive to bridge a chasm" due to their role in "reimaging one of the country's most complicated compound identities: Muslim American" (Gigerenzer, 2010, p. 29). He won the honor of being "An Influential Muslim American Artist" that was awarded by the State Department, and due to his prolific work in journalism, he was also appreciated as a "Muslim Leader of Tomorrow." He became the addressee of the Muslim Public Affairs Council's prestige recognition of 2009. In 2010, he received the Otto Award for Political Theater because he is a writer-activist (The Domestic Crusaders, 2016, p. i). As a talented Muslim writer, he feels the necessity to fulfill his duty of expressing the dilemma of his people, especially that of Muslims living within Western societies.

The Domestic Crusaders was published in 2016, and it sets out to comprehensively interpret the characteristics of Islamophobia, the causes, and the consequences. As perceived by Muslim and non-Muslim communities, Islamophobia "plays a critically central role in convincing many that a civilizational clash will be inevitable and all-consuming by establishing an essential and irreconcilable difference between 'them' and 'us"' (Gottschalk \& Greenberg, 2008, p. 3). Ali sheds light on the daily suffering of these Muslim minorities living in Western societies. It is interesting to notice that underneath the psychological and familial realism of the story, the family's trauma arises. In the of the All-Party Parliamentary Group on British Muslims, Abbas (2006) presumes the crucial roles of such texts since they correct the false perceptions of the "pervasive anti-Muslim rhetoric that has penetrated the practices of media, politics, organizations, and community relations. It is anti-Muslim action, sentiment, belief, and even propaganda" (p. 2). The heroic mission of writers such as Said and Ali is that they would not hesitate to use their talent to defend their people and culture.

The Palestinian-American thinker, critic, and writer Said (1935-2003) is known to provide political insights into the Middle East's postcolonial conditions. In his writing, he is concerned with reversing the misinterpretations of the Middle East by disambiguating the concealed ideologies of the Western media. He (1997) claims that the media keep reinforcing the deluded opinion of "Israel as [a] victim" and "demonizing the Arabs" (p. xxi). The title of the book Covering Islam refers to how "Islam is covered and (mis)represented in Orientalist thought and media stereotypes [to the extent that] it stands charged and convicted without need for supporting arguments" (p. xviii). The importance of the book lies in its discussion of the role of the Western media in the growth of Islamophobia. Said postulates that "the media have covered Islam: they have portrayed it, characterized it, analyzed it, given instant courses on it, and consequently, they have made it known" (p. li). According to this description, Muslims need to lose the shackles imposed on them by the media not only to uncover the true essence of Islam but also to expose the involvement of the media in the propagation of Islamophobia. Said admits that "the overall interpretive bankruptcy of most — though by no means all — writing on Islam can be traced to the old-boy corporation-government-university network dominating the whole enterprise [which] 
finally determines the way the United States views the Islamic world" (p.152). Muslims have to invest all their effort to unmask and stop these vicious networks.

\section{Literature Review}

In this study, a review of the ideology of Islamophobia is needed for a better understanding of the two chosen texts. The postcolonial reading of $9 / 11$ and media imperialism will be reviewed concisely because they are directly connected to the scrutiny.

\section{Islamophobia}

The creation of new ideologies is one of the characteristics of our modern world. Islamophobia is one of these trending ideologies. According to Runnymede Trust Report (1997), Islamophobia is a "shorthand way of referring to dread or hatred of Islam and, therefore, to fear or dislike all or most Muslims" (p. 1). Most Islamophobic discourse relates the reasons for this ideology to "an antipathy based on faulty and inflexible generalization" (Allport, 1955, p. 9). Other reasons that lead to the fear of Islam are racism, prejudice, and bias (Johnson and Lecci, 2003). On the other hand, Lopez (2011) often uses Islamophobia interchangeably with racialization, discrimination, stereotypes, and racism. The paper scrutinizes the role of the Western media in the spread of Islamophobia.

Postcolonial reading of $9 / 11$.

The events that happened on September $11^{\text {th }}, 2001$ were worldwide. The term $9 / 11$ is used to refer to everything that happened on that day and the impact of these events on the lives of millions. These tragic incidents have brought postcolonial studies, American studies, and ethnic studies together into one intersection. Many researchers have been busy to renew the postcolonial theory and connect it with the current changes that resulted from this dilemma. Meek (2010) defined 9/11 as "iconic cultural trauma - relived and retold in numerous documents and dramatizations" (p. 6). Barber (1995) considered the effects of $9 / 11$ on the theory of postcolonialism as "a body blow" especially regarding "valorization of ambivalence and hybridity" (p.199). Moreover, Morton and Boehmer (2010) commented on the relation between "postcolonial writing and theory, and the phenomenon of terror" (p. 2). They condemned how the supposed "discourse of terrorism" started the spread of Islamophobia (p. 11).

Media Imperialism

In the introduction to the twenty chapters of Media Imperialism: Continuity and Change, BoydBarrett and Tanner (2020) extended the definition of media to include the organizations that "own the news, telecommunications, film and TV, advertising and public relations, music, interactive games, and internet platforms and social media sites" (p. 2). Interestingly, they related media imperialism to cultural imperialism and discussed the influence of both on "media systems and cultures of other countries especially those in the global South" (p. 1). The study focuses on these imperialistic effects that lead to the spread of Islamophobia with special attention to TV as the source of the news.

Arab World English Journal for Translation \& Literary Studies 


\section{Wajahat Ali and Edward Said}

Muslims need to know that these processes of demonizing Muslims adopted by the Western media are, in Said's (1997) words, "misleadingly full, and a great deal . . . is based on far from objective material" (p. ix). They puff their writings with ideas about Islam that are "licensed [with] not only patent inaccuracy, but also expressions of unrestrained ethnocentrism, cultural, and even racial hatred, [and] deep yet paradoxically free-floating hostility" (p. 2). For such prejudiced people, the Islamic world is known mainly to them only through "newsworthy issues" such as oil and/or terrorism (p. 16). Said carefully differentiates between the Western and the non-Western or third world media because "the audiences differ, the organizations and the interests differ" (p. 47). It also goes without saying for the same stated reasons that the American media differs from the European media. Said believes that "every American reporter has to be aware that his or her country is a superpower with interests and ways of pursuing those interests that other countries do not have" (p. 47). These obligations and duties have many serious consequences for Islam.

Both texts deliberate mainly on the American and not the Western media. The Domestic Crusaders is an appeal to view the life of a Muslim family as a terrible reflection of all the mistreatments felt by all the family members. In the face of Western calls for Islamophobia, it has shouted loud and clear and with force to demand that they modify their stereotypical and distorted images of Muslims. The play focuses on a day in the life of a three-generations of a simple Pakistani American family, but a multi-layered account about the family is presented in the text, which deals with generational conflict, love, fear, food, secrets, worries, and pains. The real events of the play unfold over a single night but the author's brilliant use of flashback provides insight into the painful stories about the things that happened years ago to almost all the characters. In a concise review of the play, Newsweek (2018) posts that it is true that the play "is not as tragic as Arthur Miller's Death of Salesman, and the family is not as dysfunctional as the Irish-American family in Eugene O'Neill's Long Day's Journey, but it still fulfills what its writer wants to" (p. 2). Ali wants to confute the generalization that after 9/11, all Muslims are terrorists "unless they could prove themselves innocent of either being terrorists or sympathizing with terrorists" (Abrahamian, 2003, p. 538). This sort of perception produces what is known as Islamophobia. According to the Merriam-Webster (n.d.), dictionary, a phobia is an "exaggerated, usually inexplicable, and illogical fear of a particular object, class of objects, or situation" (n.d.). In this case, it usually refers to the fear of Islam.

The reproduction of Western media events should be exact and free from prejudice, but this is not the case. What happens is that "media coverage brings Muslim-American terrorism suspects to national attention, creating the impression that Muslim-American terrorism is more prevalent than it really is" (Kurzman, 2012, p. 7). Said (1997) admits the hidden agenda of these media, concluding that "what the media produce is neither spontaneous nor completely free" ( $p$. 44). Unfortunately, the reporters pick and choose what suits their interests, and they distort the actual reality. "It ought to go without saying that the media are profit-seeking corporations and, therefore, quite understandably, have an interest in promoting some images of reality rather than

Arab World English Journal for Translation \& Literary Studies 
others" (p. 49). The real questions that should be asked in this case are why they are doing so and what their aim is. Said explains that "they do so within a political context made active and effective by an unconscious ideology, which the media disseminate without serious reservations or opposition" (p. 45). They do so without any consideration of the damage they cause while they execute their discriminated racial ideology. "The Consciousness of a professional code of ethics and a way of doing things are involved in what one says, how one says it, and who one feels it is said for" (p. 46). The real question that needs to be put forward is how far the Western media fulfills these professional codes.

The play attempts to highlight specific sources of anti-Islamic stereotypical feelings. Ali and his characters know that they have a mission to correct and defend Islam and Muslims against these attacks. Ghafur, the younger son, summarizes the current situation of Muslims and the directed trends of Islamophobia. He (2016) says that these "extremists [are] using those millions to teach their perverted version of Islam" (p. 49). Being Pakistani, he is familiar with the political situation around his country. He blames the Taliban for "thinking it's Halal and Islamic to beat and lock up women. Thinking they're doing God's work." Moreover, he states, "Americans, and these Christians here, [are] thinking each and every Muslim is a Jew-hater, about to go berserkerrage and blow himself and everyone else up" (p. 50). From his perspective, the fact remains that it is the misdeed of the media that nurtures these stereotypes and generalized misconceptions about Muslims. Correspondingly, Said asserts that these "malicious generalizations about Islam have become the last acceptable form of [the] denigration of foreign culture in the West." The bleak irony in this situation is that whatever is "said about Muslim mind, or character, or religion, or culture as a whole cannot now be said in a mainstream discussion about Africans, Jews, other Orientals, or Asians" (p. xii). The current situations of Muslims are severe because of the constant threads propagated by these media. Ghafur believes, "that's the same garbage they get day in, day out. And no Muslim does anything - we just sit and complain. Why don't we go out and tell them how it really is?" (p. 49). Clearly, Ghafur is articulating his author's views, Ali, and every other true Muslim. Some non-Muslims worldwide believe that Muslims are dangerous and blood-thirsty, so Muslims must start defending their faith and their people and clear these false accusations. Said comments on the position of Muslims around the world and states that

with some small degree of empathy, it is not difficult to imagine that a Muslim might be made uncomfortable by the relentless insistence - even if it is put in terms of a debatethat her or his faith, culture, and people are seen as a source of threat, and that she or he has been deterministically associated with terrorism, violence, and 'fundamentalism' ( $\mathrm{p}$. $\mathrm{xxi}$ ).

The media should address these concerns and immediately stop these crusades.

On the other hand, Said (1997) clarifies the racialized involvement of the media by relating the Iranian hostage crisis of 1979 in Tehran as well as the media's role that clearly shows the 
malignity of western media not only toward Iran but also toward Muslims and Islam. A small group of Muslims is typically seen as the representatives of all Muslims and Islam. In this incident, fifty-two American diplomats were held hostage for 444 days by a group of Iranian college students. Said (1997) explains that the reasons behind his choice of this "Iranian Story" as "a good occasion for examining the media's performance is exactly what made it understandably agonizing for so many Americans: its duration and the fact that what Iran came to symbolize represented American relations with the Muslim world" (p. 77). The Western and American media

purported ... to prove that Islam was one unchanging thing that could be grasped over and above the remarkably varied history, geography, social structure, and culture of the forty Islamic nations and the approximately 800,000,000 Muslims who live in Asia, Africa, Europe, and North America (p. 79).

These biased media reporters tend to vary their tendentious techniques in their wars on Islam. They suggest that "invisible lines connected various other aspects of the [Arabic] Middle East to [Persian] Iranian Islam [and] then damn them together" (p. 80). The irony is that many people, even Muslims themselves, tend to blindly believe and adopt such distorted thinking patterns because of the hegemonic place from which these reporters are speaking.

This ironic and dichotomic conception about Islam is discussed in detail by Said (1997). He posits that this tragic situation "has spawned a set of counter-reductions [in Western nations] and in the Islamic world itself. 'Islam' can now have only two possible general meanings, both of them unacceptable and impoverishing" (p. 55). On the one hand, the Western society regards Islam as "a resurgent atavism, which suggests not only the threat of a return to the Middle Ages but the destruction of what is regularly referred to as the democratic order in the Western world" (p. 55). For them, Islam calls for violence and extremism. On the other hand, Said proposes that for "the first time in history (for the first time, that is, on such a scale), the Islamic world may be said to be learning about itself by means of images, histories, and information manufactured in the West" ( $p$. 53). Now, Muslims consider the West as their source of news despite their knowledge of how the West regards them. They see lies, and instead of correcting them, they adopt them as their own.

Moreover, the bitter irony is expressed in Ali's (2016) play through the voice of a FEMALE COMMENTATOR on the television:

FEMALE COMMENTATOR: (Voice-over) This war will end only when these monsters and terrorists and Al-ka-eeda and fundamentalist regimes renounce their hatred and extremism and learn to love and embrace democracy and freedom and American values, such as tolerance and separation of church and state and, God willing, good hygiene, ha! MALE COMMENTATOR: (Voice-over) Ann, how do you expect them to love us when we're invading their countries and bombing their homes? 
FEMALE COMMENTATOR: (Voice-over) That's the problem! They don't understand. They just don't get it. We're not invading them. Hello, stupids! We're liberating you!" (pp. 92-93)

Clearly, the play depicts the far-reaching impact of the Western media, which fuels the rise of Islamophobic sentiments among the Western as well as Islamic societies. Here, the reporter addresses the Muslim world as monsters, jihadists, and followers of "Al-ka-eeda." They spin a web of hatred around all Muslims. Other commentators talk as if the world of Islam were more or less identical with the Arab world, whereas a majority of Muslims are not native Arabic speakers. Ironically, even the Muslim world depends on the Western media for news. Thus, as Said (1997) explains, Muslim countries have transformed "from being the source of news" to "the consumers of news." They started to depend on these Western media and reporters as reliable sources of news. Unfortunately, this is "an accurate, though extremely depressing, picture of what the media revolution [that is] serving a small segment of the societies that produced it has done to "Islam"' (p. 53). Moreover, Said suggests that almost none of the "important journals of opinion" use Muslim or Arab critics to put forward their opinions of Islam as insiders. Instead, they use biased Western experts "to interpret political and cultural actualities shaped not by the facts but by unexamined presuppositions" (p. xxvi). This final idea explains the extent of anti-Islamic stereotypes and images that is prevalent in the media.

Surely enough, the kind of media Ali (2016) presents in his play is television, which is at "the top of the media pyramid" and "without doubt, the most powerful medium of mass domination ever invented." No wonder that El-Sharif (2001) righteously designates it as "the instrument of cultural genocide" (para. 16). In his play, Ali attributes a dominating voice to the television to explain, amplify, or show the general sentiments against Muslims. This voice is so powerful that one may consider it for a character in the play. It has the power to stop the family's conversation when it has to announce something. Primarily, the media is responsible for propagating Islamophobia. Due to its authoritative role, it is now a fact that "to be a Muslim is to be a distrusted Other" (Gottschalk \& Greenberg, 2008, p. 11). Fourie (2001) states that media play an essential role in furthering one group's interests over the other. These interests could be political, economic, and/or social. The critical question to be asked here is the following: who has the power and the means to shape people's opinions all around the world? "This power is mainly vested in those who own the media and who have the financial means to own and manage the media" (p.122). In the play, the discriminatory and racist voice of the television can penetrate the silence with cruel and impolite comments, especially about the war against terrorism. The following lines are overpowered by feelings of revulsion, hatred, and discrimination.

The TV: (Voice-over) The president urged the nation today not to fear or doubt, even though the battle against extremism and evil will be long and painstaking, with unfortunate but inevitable sacrifices. According to the president, these sacrifices are necessary to ensure 
our freedom and to help protect the liberties and values of all freedom-loving people against those dedicated to tyranny and hatred. (Ali, 2016, p. 44)

The play cleverly reminds the audience about the ancient notion of the White man's alleged burden of civilizing human beings, which forcibly exhorts the false justification behind the colonial conquest of the indigenous lands.

CNN HEADLINES NEWS: (Voice-over) The Soldiers of Peace, an Evangelical group with a loyal membership headed by Revered Edwards, spiritual counselor to the president, say they are ready to send over two thousand, as they call themselves, 'lovers of Christ' to help preach the gospel as soon as the army decides it is safe for American citizens and missionaries to reside in Iraq. (p. 48)

These lines explain why such reporters believe that they make positive contributions to their nations by exposing the dangerous Muslims on television. Said (1997) discusses the same idea when he provides examples of several seemingly "prestigious, high-profile news programs [that] broadcast several segments discussing Islam as a crusading religion including the warriors of God" (p. xxvi). Such attempts by these writers, among others, help in clarifying the situation and show Muslims that they should not believe everything they see/hear in these media.

Correspondingly, Said (1997) manages to showcase the diverse and, usually, biased nature of Western and American news reporters and TV hosts in their coverage. The so-called experts have managed to supply their audience with many "coarse and blind" facts about Islam and Muslims (p. 93). These facts need to be corrected. It really does not matter "whether they did so consciously or not." These media reporters "were, in fact, using their powers of representation to accomplish a purpose similar to that intended by the United States government in the past: namely, the extension of an American presence (. . .) the media's purpose seemed to be to wage a kind of war against Islam" (p. 95). After consistent exposure to a particular narrative, people tend to believe what these TV. reporters say or as Said (1997) concludes, that "the scene before us is not what a television company has caused to appear before us in this way but that it is indeed the way things are" (p. 44). This situation is the real danger of the stereotypes promoted by the media about Islamic society. Said's ideas are accompanied by the literary and theatrical talent in Ali's Domestic Crusaders. The most important contribution of the play is that it allows Muslims to articulate their truth. Ali allows his characters the chance to remark on this discrimination.

Salman: Tired OF THIS GODDAMN HEAT . . Goddamn media.

Same nonsense every day! Blame Islam. Blame Muslims. Blame immigrants for everything! Tired of the daily propaganda! . . . Who's that? Right_-another Amreekan general telling me why the Muslim world hates us. Amreeka, everyone is an expertmorons, absolute idiot, liars running this country, the worthless media, the oil companiesMuslims - useless also-stabbing you in the back. (Ali, 2016, p. 23) 
These angry words of the father succinctly express the grave condition that Muslims currently find themselves in and their reactions to the news they regularly watch, i.e., the reports produced by the biased Western media. He asked a very crucial question, "Who's that?" The audience should make such inquiries before embracing the opinions of these reporters. Salman's angry remarks are also echoed by his father, Hakim when he says the following:

Hakim: (Visibly disgusted) Just like the British — typical colonizers, imperialists, just like the ferengi Europeans. Come in — rape, loot, destroy, [and] turn brother against brother and countryman against countryman just for dawlat and power. Man never changes. (p. 48)

Here, he refers to the long colonial and postcolonial history of the relations between Muslims and Christians.

Interestingly enough, from the beginning of the play, we learn about "the injury" or "the bloody thing" in Hakim's chest that "still lingers after all these years" (Ali, 2016, p. 36). We have to wait till the end of the play to know the story behind that injury. The old grandfather suddenly feels that he should tell his family "what [he] used to do in India (his eyes are glazed)." It is indeed in such times that the power of flashback is needed to highlight specific events and provide the necessary explanations. He "(positioned center stage and talking directly to the audience, begins his story. He is physically present but immersed in his nostalgia)" (Ali, 2016, p. 97). He starts narrating how he became a killer to avenge the murder of two of his Muslim friends, Amir and Umair, who were killed by a "Hindu mob." One of them was stabbed with a knife and the other "was found hanging from a tree. They cut his stomach and let his guts hang out" (p. 98). The mob kept killing Muslims. He could not stand this and decided to take revenge. It is only then that he "learned how easy it is for a man to lose his soul." After that, he tried to escape from India, but he was shot in the chest. "The scar is forever a part of me. It reminds me of the violence, the hatred, the death, [and] the suffering that I both experienced and was responsible for . . . it is my punishment." Clearly, the guilt of his acts weighs heavily on him. He "would give anything, [his] entire life twice over, just for the memories to go away. Just to forget the screams. But [he] cannot" (p. 101). He concludes that during that time, violence was the answer to all his problems. Yet, when Fatima asked him if he regrets what he has done or if he would "have done anything differently after all that death and chaos," he replies after thinking silently for a moment,

I don't know. I just did what I felt was right at the time. Not a day goes by that I don't remember my actions or the men, all of them, who were killed. The Muslims, Hindus, Sikhs, and Christians. But I cannot change the past. (p. 103)

Should someone like him be blamed or accused of terrorism because he decides to take the law into his own hands, even after he went to the police and they did nothing? This question is worth contemplating, especially since "a person can never really know [what he will do] until he faces that situation. You have to trust yourself at that moment and do whatever it takes...as long as you 
take a stand and act honestly." (p. 104). He knows that no one feels the way he has handled, not even TV reporters. He asks, "by talking about it, you think, they think, [that] you can understand what it means to kill someone?" (p. 101). This story has nothing to do with the media and its role in the propagation of Islamophobia. The fact remains that such incidents mirror the past experiences of some Muslims who have lived and suffered from racism, and they show how such attitudes against them shaped their present lives. It reflects the horrible outcomes of hatred, discrimination, and anger. The scar that this old man is carrying on his chest announces to the whole world that the true nature of Muslims is not that murderers, but they are often forced to commit criminal offenses.

After reading the play, it is clear that all the humiliation that these characters narrate is, as explained by FATIMA, the result of "a blatant racial profiling which any Muslim might face in life just "cause [he] has an Arab-sounding name." There are real troubles that he will face if he has a beard, which is a clear "sign saying, I'M AN EXTREMIST. ONE WAY TICKET TO ABU GHRAIB, PLEASE.” (Ali, 2016, pp. 40-41). When SALMAN brings his nail cutter to the airport, FATIMA tells him, "you're lucky they didn't just strip-search you. Hose you down and do some Superman scan of your internal organs while they were at it" (p. 38). This humiliation and misrecognition "can inflict harm, can be a form of oppression, imprisoning someone in a false, distorted, and reduced mode of being" (Taylor \& Gutmann, 1994, p. 74). In the play, Ali uses these examples along with many others to racialize the stereotypes against Muslims that are used viciously to portray them as violent terrorists and tricky, regularly disgusting, and hardly humans. Of course, it is clear after reading the play that Ali's goals are articulated by Ghafur, who wants "to make people unlearn all the misinformation they've been forced [to learn] their whole lives about Muslims, Islam, Arabs, and the Middle East" (Ali, 2016, p. 55).

On the other hand, Said (1997) has another mission in mind, i.e., to dig deep into the reasons behind these situations and to explore their results. He confidently assures his readers that most of these false and biased ideas about Islam and Muslims are the results of "wild exaggeration of the sensationalist and ignorant American [and Western] media." The fact remains that all these Islamophobic feelings and attitudes are "taken from anti-Islamic careerist publicists who had found a new field for their skills in demonology" (p. xxvii). He believes that this is a sign of power and dominance. In the world that we are currently living in, "the mere assertion of an Islamic identity" requires "a necessity for survival" (p. 72). For the Western media, this power gives them the right to say

what they wish about Islam because they can, with the result that Islamic punishment and "good" Muslims (in Afghanistan, for instance) dominate the scene indiscriminately; little else is covered because anything falling outside the consensus on what is important is considered irrelevant to the interests of the United States and the media's definition of a good story. (Said, 1997, p. 142) 
To get a good story, they are ready to eliminate elements of the truth and misrepresent the other parts to fulfill their warmongering missions.

The focus of the two texts is the cross-culturalism perceived by the two writers from the Muslim world, and the paper intends to provoke more discussion and analysis. On the one hand, Ali's play manages to discuss some identity abuse patterns or what Taylor and Gutmann (1994) call the "non-recognition or misrecognition." They postulate that usually, the identity, especially of minorities, is

partly shaped by [its] recognition or its absence, often by the misrecognition of others, and so a person or group of people can suffer real damage, real distortion, if the people or society around them mirror back to them a confining or demeaning or contemptible picture of themselves. (p. 25)

In the play, almost all family members suffer from certain kinds of misrecognition. On one side, because of their outfit or their names, they are either "Afghanis" or "related to Osama bin Laden" (Ali, 2016, p. 16). On the other side, everyone in this family has their problems and worries. For example, Salman, the father, regularly faces discrimination at work. For the men in the company, he is only the "brown, foreign, Muslim dog — a Muslim camel." After working for thirteen years in the company, his boss "still thinks I'm from India. India, Pakistan, Afghanistan, what's the difference?" The Americans, he knows, keep calling him SAL because it "was too hard for [them] to pronounce these A-rab names." Unfortunately, Salman knows that "as a foreigner, you're going to take a beating, you'll always take a beating. But inshallah, when you make your gold, don't wipe your blood off the street. Keep it there, to show all of them that you have earned it" (p. 79). This is the American dream or nightmare from which this family and almost all immigrants are suffering.

\section{Conclusion}

To conclude, it is noteworthy to say that this study was inspired by an interest in the field of the East-West relationships, especially after 9/11. The importance of the paper lies in its attempt to change Eurocentric sentiments against Muslims and Islam. In addition, the paper uncovers the media's role in the spread of Islamophobia. The rereading of the two texts shows the cultural, social, and political dilemma of Muslims in the face of the ruthless policies of the Western media. Among the complications of 9/11, many Muslims all over the world find themselves forced to defend their religion, culture and their people. In the face of the vicious crusaders of the Western media, many writers and thinkers have started to use literature as the media to narrate the problems of assimilation and racism.

The two writers have attempted to confront the violent and stereotypical images of Muslims in political and social life using their art. Their contribution to this field is necessary and relevant, as Muslims have become the talk of the hour through false associations with terrorism and 
fundamentalism. Almost all these writers have to try their best to defend Islam and Muslims from the stigma of terrorism is incredibly dehumanizing. Unfortunately, these writings that "aim to humanize [Muslims] can end up reconfiguring or reversing or even reinforcing [the] processes of dehumanization" (Franklin, 2017, p. 859). Such writers need to be careful when they pour their hearts out to their audience.

Ali (2016) endeavors to show the ambivalences and hardships experienced by Muslims after 9/11. His two-act play has managed to correct the disfigured, stigmatized, and stereotypical images of Muslims in general and Pakistanis in particular. The play narrates the instances of discrimination that all Muslims and even those who only look Muslim are subjected to. Said (1997) indeed focuses on American media while Ali focuses on the British media. However, both discuss the demonizing effects of these media on Islam. The views of the outstanding postcolonial critic are conveyed in the play with the aid of the literary and theatrical abilities of Ali. The two writers have helped portray this cultural issue as a modern religious crusade against Islam and Muslims using media. Hence, the research is a vital re-examination of Ali's play in light of the postmodern ideas of Said's book. The media's role is significant in reshaping the opinion of the global audience. This could be a call to utilize the same weapon to defend Islam and Muslims if we want to change the widespread stereotypical image associated with them.

In addition, Said's (1997) book indeed discusses certain historical events. His words and thoughts are expressive of severe and fundamental human interactions. He comments on the ideas of power and hegemony concerning to the false interpretations of Islam due to the stereotypical biased thinking of media reporters. These reporters use their authoritative voices to transform reality while reporting. Ali (2016), on the other hand, gives TELEVISION the voice to not only comment on the events that are going worldwide but also to lead to counternarratives that the characters relate to. Despite the differences in their methods, the two texts urge the readers to verify the validity of what is happening in front of them and what they hear and watch on the media.

\begin{abstract}
About the Author:
Maram Mohammed Samman is an Assistant Professor of English Literature at Taibah University, Madinah, Saudi Arabia. She is the Deputy Head of the Languages and Translation Department. She earned her $\mathrm{PhD}$ in English Literature from King Saud University in Riyadh. Her current research interests focus mainly on drama and cross-cultural comparisons of postmodern cultural and literary movements. ORCiD: https://orcid.org/0000-0003-2515-6987
\end{abstract}

\title{
References
}

Abrahamian, E. (2003). The US media, Hunting, and September 11. Third World Quarterly, 24(3). pp. 529-544. https://doi.org/10.1080/0143659032000084456

Ali, W. (2016). The Domestic Crusaders. San Francisco: McSweeney's Books. Allport, G. (1955). The nature of prejudice. Cambridge, Mass: Addison-Wesley Pub. Co 
Barber, B. (1995). Jihad vs McWorld. New York: Routledge

Boyd-Barrett, O. \& Tanner M. (2020). Media Imperialism: Continuity and Change. London: The Rowman \&Littlefield Publishing Group.

El-Sharif, O. (August 20, 2001). Media Imperialism in the Global Era. Middle East News Online. ProQuest Central. Available at https://search.proquest.com/docview/203075150

Gigerenzer, T. (December 16, 2010) Muslim American Artists Strive to Bridge a Chasm. New York Times, 29. Available at https://www.nytimes.com/2010/12/17/us/17bcarts.html

Gottschalk, P., \& Greenberg, G. (2008). Islamophobia: Making Muslims the Enemy. Lanham: Rowman \&Littlefield Publishers, INC.

Fourie, P. (2001). Media Studies: Institutions, Theories, and Issues. South Africa: Juta Education. Franklin, C. (2017). Narrative Humanity at the Intersection of 9/11 and Katrina: Dave Eggers's Zeitoun. American Quarterly, 69 (4). pp. 857-881. Available at https://10.1353/aq.2017.0070

Johnson, J. D., \& Lecci, L. (2003). Assessing Anti-White Attitudes and Predicting Perceived Racism: The Johnson-Lecci Scale. Personality and Social Psychology Bulletin, 29(3), 299-312. https://doi.org/10.1177/0146167202250041

Kurzman, C. (2012). Muslim-American Terrorism since 9/11. Triangle Center on Terrorism and Homeland Security. Durham, North Carolina University Press. Available at http://kurzman.unc.edu/files/2011/06/Kurzman_MuslimAmerican_Terrorism_Since_911_An_Accounting.pdf

Lopez, F. (2011). Toward a Definition of Islamophobia: Approximations of the Early Twentieth Century. Ethnic and Racial Studies. 34 (4). pp. 556-573. Available at https://doi.org/10.1080/01419870.2010.528440

Morton, S., \& Boehmer, E. (2010). Terror and the Postcolonial. London: John Wiley \& Sons Ltd.

Meek, A. (2010). Trauma and Media: Theories, Histories, and Images. New York: Routledge

Merriam-Webster. (n.d.). Phobia. Merriam-Webster.com dictionary. Retrieved from https://www.merriam-webster.com/dictionary/phobia

Newsweek (2018). The Domestic Crusaders' Shows Muslim-American Struggle after September 11. (Nov 12, 2018). Newsweek. Available at https://www.newsweek.com/domesticcrusaders-shows-muslim-american-struggle-after-september-11-220760

Rane, H., Ewart, J., \& Martinkus, J. (2014). Media-Generated Muslims and Islamophobia. Media Framing of the Muslim World, 29-46. London: Palgrave Macmillan. https://doi.org/10.1057/9781137334831_3

Runnymede Trust Report. (1997). Islamophobia: A Challenge for us all. London: Author

Said, E. W. (1997). Covering Islam: How the Media and the Experts Determine How We See the Rest of the World. New York: Random House.

Taylor, C., \& Gutmann, A. (1994). Multiculturalism: Examining the Politics of Recognition. Princeton: Princeton University Press. 